\title{
WOMEN AND POWER IN THE POLITICAL THOUGHT OF DAYAK MA'ANYAN TRIBE
}

\author{
Kisno Hadi \\ University of Christian Palangka Raya, Indonesia \\ Email: kisnohadi@yahoo.co.id
}

\begin{abstract}
In the political thought of Dayak Ma'anyan in Central Kalimantan, especially in East of Barito Regency, the role and status of women and men is equal. These roles and status were accommodating in adats concept and adat law of Dayak Ma'anyan which is said that women can get a strategic position in public area as in the traditional political context. Surprisingly, in the political history of Dayak Ma'anyan, their first leader is a woman. Her task was to organize and to order all people of the tribe. In mythological, it is believed that the woman leader earn the leadership skill and regulation on adat directly from Gods as a gift and these regulation still apply by the tribe in their daily life. Because of the belief, women of Dayak Ma'anyan are welcome to participate in public area, political, social, adat and cultural. This article is a research which is use descriptive method with interpretative qualitative data analyzes. The research is done on May, 2015 to March, 2017 in the region of Dayak Ma'anyan: in South Barito Regency and East Barito Regency, especially in Paju Epat District. Paju Epat District believed as a center of descendant of Uria Napulangit, e.c the descendant of Nan Sarunai Kings. Dayak Ma'anyan Paju Epat was called "Tutur Mantir" (leader group), where live in Balawa, Siong, Telang dan Murutuwu villages. Writer gain information by deep interview with local adat leader e.g Mantir, Damang, Pangulu Adat, and Pamakal. Also from oral source data e.g Taliwakas (stories on leader), Hiyang Wadian (sacred song of ritual priest), Sorosilah (history of leader) and adat law of Dayak Ma'anyan. Then Data interpreted by using theory of political thought on power and sources of power of Charles F. Andrain.
\end{abstract}

Keywords: Women, Political Thought, Sources of Power, Dayak Ma'anyan Tribe, Adat 


\section{INTRODUCTION}

Issue on women's contribution in public area is still a hot issue so that it is suitable for the theme for International Women's Day 2019 "Think equal, build smart innovate for change". In the modern era issues on roles and status of women in public area, especially in the political arena are still considered as significant. Norms and Adats that held by the people have two faces: on the one hand allow women to contribute in public area but at the other hand, forbid them to participate in public area as equal as men. For many years, women still face barriers to contribute in public life and forced to silent as usual.

In the opposite of the situation, in the midst of Central Kalimantan there is one tribe that has adats that give women an access to achieve and receive highest position in the political power. The tribe called Dayak Ma'anyan. Population of Ma'anyan tribe is about 2,80 percent from total population of Central Kalimantan (Suryadinata, 2003: 26). Historically, long time ago Dayak Ma'anyan was one of tribal group of Central Kalimantan that has a powerful kingdom called Nan Sarunai. Nan Sarunai Kingdom was recognized as a victorious kingdom about 13-14 CE century and it's formerly ruler was a queen, named Nini Punyut. According to tradition, it is believe that the queen was had received a compilation of adats and life regulations as a gifted of Gods to her that she will be the ones who has power to manage and organize Dayak Ma'anyan people. Nowadays, the compilation of Adats and life regulation is still preserved and implemented as Adats Law of Dayak Ma'anyan people both adats on daily life and death ceremony. And the spirit of women as a good and a powerful leader strongly adapted by Dayak Ma'anyan people until now: women and men have equal roles both in domestic and in public areas.

Ukur, a historian and a writer who write many books on Dayak Ma'anyan's culture, said that in Dayak Ma'anyan there are some cultural characteristics as symbols of power i.e. Rumah panjang (long house), Mandau (a kind of sword) and sumpit (a kind of blowpipe), cultivation system and position of woman in society (Ukur, 1992:6-10). Those characteristics considered and claim as a symbol of power of Dayak leader also. According to this notion, a leader position of women in public and society in Dayak Ma'anyan tribal group is normal, valid and legitimated.

Cultural symbol that respect to women and give legitimating on capacity of women leadership in Dayak Ma'anyan tribe can be trace its location for example in East Barito Regency. Many women involved both in a parliamentary election and in a Regent Election. For example in 2018 there was a woman became a candidate of Regent in the Regency election in East Barito Regency. Although she was lose, her participation in that election described on how people in that regency, in inland Kalimantan, appreciate to women's contribution in public. So, it is also commonly recognize that women elected as an Adat leader, as Penghulu Adat. Those facts describe that culturally, women are equal to men in roles and position in Dayak Ma'anyan tribe. Then a challenging question arises: "what is exactly women's power position in the political thought in Dayak Ma'anyan tribe?"

This paper trying to uncover the answer of a question above by doing research on power in the political thought in Dayak Ma'anyan's tribe. Locus of the research was 
Dayak Ma'anyan people in the East Barito Regency in Central Kalimantan. Research then came to discover two major reasoning to answer the question: first, there are some Adats conceptions which are actually describing on women leadership, inheritance of women's leader power and the honorary degree for women's leader; and second, roles and positions of women in modern political.

\section{METHOD}

The research for this paper is using descriptive method and the data is analyzed based on interpretative qualitative. Research that based on interpretative qualitative is a kind of research that revealed various phenomena and social realities ideographically, so the theory that produced will strongly fixated in realities, contextual and historic (Somantri, 2005: hal. 64).

Locus research as an analysis unit was Dayak Ma'anyan tribe who lives in East Barito Regency, especially in Paju Epat District and in one part of South Barito Regency from March, 2017 - April 2019. Paju Epat District is a term that derives from 2 words: Paju means Kampung (village) and Epat means empat (four). So, Paju Epat means empat kampung/kampung yang berjumlah empat (four villages). These four villages are Balawa, Siong, Telang and Murutuwu. Paju Epat has known as a "house" of descendents of Uria Napulangit, i.e. the descendents of Nan Sarunai Kings then became an Elite group called Tutur Mantir (Leader group). Researcher was doing deep interview to Adats leader i.e. Mantir, Damang and Pangulu Adat. Also using oral data named Tali Wakas (Story on Dayak Leader), Hiyang Wadian (holy song of priest in Adats Ritual), Sorosilah (history of leader legends), and Adat Law of Dayak Ma'anyan. Then researcher interpret Data by using theory of political thought on power of Charles F.Andrain.

\section{DISCOURSES}

April Carter said that one of attempted to understand on power was to gain forms of original power in historical and social context (Carter, 1985:7). That traditional power was held based on the strong believe to the old traditions (Ben Anderson, 1984:47-50). For Ukur, to understand the way of thinking of Dayak Ma'anyan tribe, someone has to explore and understand about Adats and traditions that appear from myths (Ukur, 1974: 4). Although sometimes we felt that myths is unrealistic not logic but it sometimes hiding a precious facts (Borneo Intitut, 2013: 10).

The one form of original power in Dayak Ma'anyan tribe is in Nan Sarunai's chronic. In that chronic, acknowledgment of women in power and in political thought of Dayak Ma'anyan is revealed. Conception on source of power also stored in that chronic. There are five kinds on source of power i.e,: first, primordial sources such as ancestry, or descendent of certain figure that has privileged to lead some area and political party; second, as a gift of sacred things such as gods; third, from their personal belonging such as property, wealthiest, generosity, or the position as figure in society, as a religious figure. Fourth, from instrumental sources such as in riches of experiences, higher education, achievement; and fifth, in constitutional nation, power came from legally and procedural law (Andrain, 1992: 194-197). 
Page 698-707,. ISBN: 978-602-6 988-75-1

Web Jurnal Online: jurnal.unmuhjember.ac.id

By: Kisno Hadi;

Women And Power In The Political Thought Of Dayak Ma'anyan Tribe

Ramlan Surbakti then classified 4 of Andrain's theoris on sources of power as a substantial sources, i.e., a right to govern that based on factors that owned by the leader such as tradition, as a charismatic figure and personal qualities. And a procedural or factual power. Someone to be a leader because of constitutional reason (Surbakti, 1992: 85-88). Referring to theories of sources of power of Andrain and Surbakti, in the political thought of Dayak Ma'anyan tribe, its sources of power can be identified for 2 sources: procedural sources and substantial sources.

Procedural sources are constitutional laws: written and oral laws (Adats). Substantial sources is supernatural sources such as (1) Alatala (God) and Nanyu (gods ar ancestries; (2) Panatau (property), (3) Galar Mantir (leader titles), (4) Pusaka Keagungan (power symbols), and (5) Tutur or Hurui (genealogic).

\section{CONCEPT OF ADATS AND WOMEN LEADERSHIP}

Adats in daily life manifested in Adats law but in political thought of Dayak Ma' anyan tribe, conception of Adats (Hadat) itself is broader than Adats law and beyond of it. Adats (Hadat) understood both as laws, ritual, tradition, religious rites, social rites and leader group tribe governance. All of human aspects in daily life of Dayak Ma'anyan people is categorize as Adats (Pilakoanu, 2010: 153). Adats law that nowadays practiced by Dayak Ma'anyan is believe as a heritage of Nan Sarunai Kingdom era. Since 13 and 14 century, adats law was using as a constitutional of the kingdom or tribal group life. In their historical politics, adats law is using in many phases of leadership in tribe as describe:

1. in Tumpuk Laliku Meah (before 1305 CE). Centered in Hujung Panti, near Pangambangan, Kalimantan Selatan (South Kalimantan). The famous leader was Pangulu Nini Punyut;

2. Nan Sarunai kingdom (1305-1358). Centered in Kayu Tangi, near Martapura, South Kalimantan. It's leader was Raja Anyan;

3. Bangi Sampa Tulen (1358-1389). Centered in north part of Tamiang Layang, East Barito, Central Kalimantan. It's famous leader was Dambung Mangkurap dan Uria Napulangit;

4. Tanjung Nagara (1365-1535). Centered in Amuntai, Hulu Sungai Utara, South Kalimantan. One of its famous leader was people of Dayak Ma'anyan: Uria Gadung;

5. Lasi Muda (1535-1850). Centered in Dayu, East Barito, Central Kalimantan. It's leader was Uria Biring;

6. Landschaap Sihong (1850-1942). Centered in Telang, East Barito, Central. The most famous of its leader was Suta Ono or Ronggo. He was a Regent (Bae, dkk, 1995: 109; Hudson, 1967: 89; Miter, 2017).

In Tumpuk Laliku Meah, the life of Dayak Ma'anyan is became settled. They was lead by a woman called Etoh or known as Nini Punyut. In their believe, Nini Punyut was given a gift of Dayak Ma'anyan laws. In Sorosilah (history of leader legends) and Taliwakas (Story on leadership), Nini Punyut believed as a daughter of Sawalang Gantung, (gods of Heaven) and Ungkup Batu (gods of earth). She was their first children. One day, her parents sent her to Tumpuk Laliku Meah or Sarunai. In Tumpuk Laliku 
Meah, she received a gifted of Gods because she could open a clot of yarn that thrown by gods from the heaven. In that yarn, she found 9 rules to manage on life and 7 rules to exercise on death ritual. Nowadays, the rules became 24 rules to manage on life and 19 rules to exercise on death ritual. That rules still practiced in Dayak Ma'anyan life. Two of its rules are Kawit Kinte (Learning of leadership) the rule on how to manage power and leadership and Dudus (inauguration of leader).

As a daughter of Gods and receiver of Adats law of gods, Etoh or Nini Punyut became the first leader of Dayak Ma'anyan and as a Pangulu Adats (Adats leader). She was a wise leader in Tumpuk Laliku Meah. Historically, Tumpuk Laliku Meah then became "a tribal state" that famous as Nan Sarunai, a glorious kingdom of Dayak Ma'anyan tribe.

\section{A TUTUR MANTIR CONCEPT AND A HERITAGE OF WOMEN LEADERSHIP}

Tutur Mantir concept is genealogical concept that classified leader just in the same ancestries. Tutur (hurui) understood as blood lineage because of marital or leader heritage lineage. Tutur Mantir is part of Dayak Ma'nyan law, recognized as one of source of power. Mallinckrodt (1927: 552) said that Tutur or Hurui is a national conception i.e. as a classification of family or tribe which is makes a differences one to another. Tutur Concept is using since Nini Punyut's era and still preserved as references in choosing local leader.

Since Nini Punyut recognized as a daughter of gods, so the leader believed as descendents of gods also. Structurally, Mantirs (adats Leaders) who delivered of Nini Punyut's teaches on adats laws or government institution (called by Nini Punyut as Mantir Epat Puluh Isa - artinya Mantir yang (berjumlah) empat puluh satu) are classified as a tribal group leader.

Tutur Concept that using since Nini Punyut's era is still practiced now in the context of legal government in villages. Sorosilah (history of leaders) of Nan Sarunai once said:

1. Nini Punyut (Etoh): replace Raksapateh, Singa Galanteh and Using Dukut Nungu Dapur, leading Tumpuk Laliku Meah.

2. Nini Punyut (Etoh). Started to live in Nan Sarunai, i.e., Tumpuk Sani Sarunai Gumi Ngamang Talam. Nini Punyut order people to:

a. Build house to live, called Balai Karunrung Rahu, Sarungayan Payung Uran.

b. Cultivated rice, trees, vegetables and utilized all the resources to support life.

c. Preserves on Adats laws, regulations, arts, social life, leadership and to govern the ritual on life and death.

d. arrange on leadership and create leaders who can govern the people. These leaders are called Mantir Epat Pangulu Isa (an Adats institution which are consists of forty four Mantirs, and 1 Pangulu).

3. Mantir Epat Pangulu Isa, were consist of:

a. Pangulu: Nini Punyut or Etoh, as the queen, a head of government. 
Page 698-707,. ISBN: 978-602-6 988-75-1

Web Jurnal Online: jurnal.unmuhjember.ac.id

By: Kisno Hadi;

Women And Power In The Political Thought Of Dayak Ma'anyan Tribe

b. Pamakal: Jamuhala Maleh Tuan Tana Ratu Hiang Runsa. Is the title of leaders in village level.

c. Mantir Bagawan Kanuh Upat Miharaja

d. Mantir Pahulu Paduka Ngadu Hiang

e. Mantir Ensu Kamu Pajang Malan Rahu.

4. Nini Punyut died and replaced by Raden Japutara Layar with an honorary title Datu Telang Tuha Miharaja Wulu Kesai Lawei who lead Nan Sarunai.

The sentences above briefly said about history of the kings of Nan Sarunai from history of Nini Punyut, the first queen of Nan Sarunai to religious leaders now.

Tutur Mantir Concept is part of adats law on life (hukum hadat tiba welum) number $16^{\text {th }}$. Tutur Mantir contains histories of Dayak Ma'anyan's leaders from Nan Sarunai era to recent years; start from the last Mantir in Nan Sarunai era to Mantir who leads people of Dayak Ma'anyan escape from the capital city to country site after Sarunai Usak Jawa (Sarunai destroyed by Jawa; Majapahit). The blood lineage of Tutur Mantir class is only inherent in Dayak Ma'anyan Paju Epat's leaders because the first Mantir was the descendent of kings Nan Sarunai, named Uria Napulangit. Uria Napulangit recognized as the last king of Nan Sarunai also known as the first mantir. He was lead people of Nan Sarunai escape from the city. The exodus people - brought and tried to save all of the adats law of nan Sarunai - came to Paju Epat. Then they lived in Paju Epat and preserved all of Adats law in their daily life. Regulations, rites in religious and rituals both on life and death are treated and practiced as a treasure for them (Wawancara, Batherius, 2017).

Tutur Mantir concept is a leadership conception. It tells that the leaders will succeed by the new one who has the same lineage with them, either men or women. It is common that the successor is the first child. But if the first child is rejected the position, the leader position will replaced by the second, or third child. The decision of that leaders position is also depend on adats forum. It means that adats forum (Pipakatan) is important.

The tradition of succession in Tutur Mantir Concept is unique because it gives the same right for men or women to be a leader. For example in Balawa area, one of village in Paju Epat, once ever said:

"Historically, there was a woman named Rangga Ngembe, that known as a leader in the village. She became a leader because she was the first child of her father, Mangku Kekes. Her father gives her an honorary title as "Rangga". The story tells that women as leader is a common in Balawa, Paju Epat (Mangkujati, 2003: 226).

Still in Balawa village - in genealogy of Tutur Mantir - there was a woman name Rangga Nunuk. Rangga was a leader's title for woman in political thought of Dayak Ma'anyan. She replaced Mangku Jaya. In other village, in Lasi Muda, there was also a woman leader called Pahulu Ragan (1702-1735) (Bae, dkk, 1995: 195-196). Lasi Muda (now called Dayu), was a center of government of Dayak Ma'anyan (1535-1815) before it move to Telang. In my recent research, I found that in many base home of Dayak 
Ma'anyan, many women get title as Pangulu (Adats leader), some of women are Pamakal (leader of Village) both in East and West Barito Regency.

\section{GALAR MANTIR CONCEPT AND THE TITLE OF WOMEN LEADER}

Galar Mantir concept is parallel with the leader title of tribal group. In political thought of power in Dayak Ma'anyan tribe, the title was give only to people who has fulfill some qualification. Not all the descendents of leader have a title. One of the qualifications is pangiwuruh (charism). Requirements to gain the title was regulated in adats law of Dayak Ma'anyan, i.e., first, he or she originated from Tutur Mantir class (leader family); and second, if the leader is not a descendent of Tutur Mantir class, it need some ritual i.e., Nindrik Langka. The ritual was held to avoid balas pati. Balas pati is incompetence situation to enroll position that can cause instability of power.

Galar Mantir was emerge after Sarunai Usak Jawa. The leader title in many part of Paju Epat is Dambung, then Uria, Patinggi, Damang, Sinu, Mangku, Suta, Raden, Patis, Jaksa. All of the title is equal, in role and position. But in Balawa village, the title has a different in level and in function. The first and the highest is Mangku, then Patinngi, Jaksa, Giritan, Singa-Langgawa, Djarang-Bajohan and Mangasiau (Masiau) Mallinckrodt (1927: 566-573), Ukur (1971: 67), dan Mangkujati (2003: 211). Mallinckrodt called these group titles as Pandam, the high class citizen or Putak Amau class (leader, ruler). Beside these titles, there are other groups or class that no title called non caste (Putak Ime), or Putak Walah (slave class). All the titles above are for men. For women, the title was Rangga and Pahulu.

Beside as leader in government area, women also have a role as leader in religious ritual. There is one role for women i.e., Wadian. Wadian is such as a priest of the tribe. Wadian position is very important for Kaharingan, a local religion in Kalimantan. They are responsible for any rituals in that religion i.s., Wadian Pisame (leader in ritual of Ijambe, one of Death ritual in Paju Epat Ma'anyan), Wadian Dadas, Wadian Amunrahu and Wadian Pangunraun (Mangkujati, 2003).

\section{WOMEN IN MODERN POLITICS}

Ukur said that one of characteristics of Dayak Ma'anyan culture is "the role and position ofwomen in the society". His notion is confirms in political dynamic in Central Kalimantan. Some women are having an important position in government such as Satya Titiek Atiyani Djoedir (vice-Regent of South Barito for 2 periode, 2011-2017 and 20172022). Pancani Gandrung (a Party chairman of Perindo in Central Kalimantan) and was became a candidate of East Barito Regent and a candidate of Vice-Governor of Central Kalimantan in 2015. Adelina Sendol as a Party chairman of Nasdem in East Barito Regency and now as a parliamentary member of East Barito. Ina Karuniani was a subdistrict head of Paju Epat and ever have a position as head of department of East Barito. Yangsie Hartini, as head of fraction of PDIP in South Barito Regency.

The roles and position of women mark out that in Dayak Ma'anyan those women were recognized. The involvement of women in public area is confirms and proves that Adats and culture of Dayak Ma'anyan tribe very appreciate on women. 
Page 698-707,. ISBN: 978-602-6 988-75-1

Web Jurnal Online: jurnal.unmuhjember.ac.id

By: Kisno Hadi;

Women And Power In The Political Thought Of Dayak Ma'anyan Tribe

The table below listed on women of Dayak Ma'anyan who contribute as leader in public area:

Table of Dayak Ma'anyan Women in Public area (2017 - 2019)

\begin{tabular}{|l|c|c|c|c|}
\hline \multicolumn{1}{|c|}{ Position } & $\begin{array}{c}\text { East Barito } \\
\text { Regency }\end{array}$ & $\begin{array}{c}\text { South Barito } \\
\text { Regency }\end{array}$ & Province & $\begin{array}{c}\text { In } \\
\text { Jakarta }\end{array}$ \\
\hline Regent/Vice Regent & & 1 (vice Regent) & & \\
\hline Village head & 8 & 3 & & \\
\hline Adats leader (Pangulu) & 1 & 1 & & \\
\hline Parliamentary member & 2 & 9 & & \\
\hline Political Party chairman & 2 & 1 & & \\
\hline $\begin{array}{l}\text { Parliamentary member in } \\
\text { Province }\end{array}$ & & & 1 & 1 \\
\hline $\begin{array}{l}\text { Parliamentary member in } \\
\text { Jakarta (in 2019'election) }\end{array}$ & & & & \\
\hline
\end{tabular}

In the context of Dayak Ma'anyan culture, roles and positions of women in public area are recognized. Regulation and constitution of Indonesia now also give a contribution for women to active in any level.

\section{CONCLUSION}

In the history of political thought of Dayak Ma'anyan on power, the roles and position of women are equal to men. It also proven by history of power gift to women: the women are the successor of adats law which are given by Gods. By the laws, women are having power to manage society and to perform any religious ritual both on life and death ritual. Women also recognized as the wise leader who became the first queen in the glorious kingdom of Nan Sarunai.

Women leader then create women leadership concept in Dayak Ma'anyan that still implemented until now. And in this modern era, Dayak Ma'anyan's women have contributed in public area i.e., as vice regent, parliamentary member, a chairman of political party and so on. It is confirms that roles and positions of women are equal to men. 
Proceeding ICOGISS 2019

Page 698-707,. ISBN: 978-602-6 988-75-1

Web Jurnal Online: jurnal.unmuhjember.ac.id

By: Kisno Hadi;

Women And Power In The Political Thought Of Dayak Ma'anyan Tribe

\section{References}

Agus, Arlius, dkk. Kiaen Wadian Hintek Ijambe (Perjalanan Wadian Saat Upacara Ijambe). Siong: Naskah tidak diterbitkan, 2016.

Anderson, Benedict R.O'G. 1984. “Gagasan Tentang Kekuasaan Dalam Kebudayaan Jawa”, dalam Miriam Budiardjo (Peny.). Aneka Pemikiran Tentang Kuasa dan Wibawa. Jakarta: Penerbit Sinar Harapan.

Andrain, Charles F. 1992. Kehidupan Politik dan Perubahan Sosial. Yogyakarta: Tiara Wacana.

Bae, Sutopo Ukip, Djanang G. Bandan dan Martinus. "Sejarah Suku Dayak Ma'anyan, Banjar dan Merina di Madagaskar”. Hasil Penelitian, Museum Nasional RI. Naskah tidak diterbitkan, Jakarta, 1995.

Borneo Institut. "Hapakat Manggatang Utus, Dari Kalimantan Tengah Mencari Identitas". Palangka Raya, Borneo Institut, 2013.

Carter, April. 1985. Otoritas dan Demokrasi. Jakarta: Rajawali Pers.

Gentong, Dilen dan Satimen Dusau. "Hukum Adat Dayak Ma'anyan". Buntok: Pemerintah Kabupaten Barito Selatan. Naskah tidak diterbitkan, 2004.

Hudson, Alfred B. "The Padju Epat Ma'anjan Dayak in Historical Perspective", dalam Indonesia 4, 1967, hal. 8-42.

Magnis-Suseno, Franz. 2003. Etika Politik: Prinsip-Prinsip Moral Dasar Kenegaraan Modern. Jakarta: PT. Gramedia.

Mallinckrodt, J. 1927. De Stamindeeling Van De Ma'anjan-Sioeng-Dajaks Der ZuiderEn Ooster Afdeeling Van Borneo. Amsterdam: Natherland.

Mangkujati, Anjarani. 2003. "Wadian Perempuan: Mencari Identitas Dayak Ma'anyan (Masa Kini)", dalam Budi Susanto, SJ (Ed.). Politik dan Postkolonialitas di Indonesia. Yogyakarta: Kanisius.

Miter, Hadi Saputra. "Suta Ono: Kepemimpinan Kharismatik Seorang Kepala Suku Dayak Ma'anyan Paju Epat”. Tesis, Sekolah Tinggi Teologi Gereja Kalimantan Evangelis, Banjarmasin, 2017.

Somantri, Gumilar Rusliwa. "Memahami Metode Kualitatif", dalam Jurnal Sosial Humaniora "Makara", Volume IX (2) Desember, 2005, hal. 64.

Sorosilah Nan Sarunai. Naskah tidak diterbitkan. Tanpa tahun. 
Page 698-707,. ISBN: 978-602-6 988-75-1

Web Jurnal Online: jurnal.unmuhjember.ac.id

By: Kisno Hadi;

Women And Power In The Political Thought Of Dayak Ma'anyan Tribe

Surbakti, Ramlan. 1992. Memahami Ilmu Politik. Jakarta: Gramedia.

Suryadinata L, Arifin EN, \& Ananta A. 2003. Penduduk Indonesia: Etnis dan Agama dalam Era Perubahan Politik. Jakarta: LP3ES.

Ukur, Fridolin. "Ijambe, Upacara Pembakaran Tulang di Kalangan Suku Dayak Ma'anyan di Kalimantan Tengah", dalam Majalah Paninjau, Lembaga Penelitian dan Studi Dewan Gereja-gereja di Indonesia (DGI), Tahun I Nomor 1, 1974, hal. 3 46.

Ukur, Fridolin. "Kebudayaan Dayak", dalam Majalah Kalimantan Review No. 02 Tahun I, Juli-Desember 1992, hal. 6-10.

Ukur, Fridolin. "Tantang-Djawab Suku Dajak". Disertasi, Sekolah Tinggi Teologia Jakarta, Jakarta, 1971.

Taliwakas Ma'anyan. Naskah tidak diterbitkan. Tanpa tahun.

Tulus P., Rama. “Agama Sebagai Identitas Sosial: Studi Sosiologi Agama Terhadap Komunitas Ma'anyan". Disertasi, Kajian Sosiologi Agama, Program Pascasarjana Sosiologi Agama Universitas Kristen Satya Wacana, Salatiga, 2010. 